Review

\title{
How can forage production in Nordic and Mediterranean Europe adapt to the challenges and opportunities arising from climate change?
}

\author{
Å. Ergon ${ }^{\mathrm{a}, *}$, G. Seddaiu ${ }^{\mathrm{b}}$, P. Korhonen ${ }^{\mathrm{c}}$, P. Virkajärvi ${ }^{\mathrm{c}}$, G. Bellocchi ${ }^{\mathrm{d}}$, M. Jørgensen ${ }^{\mathrm{e}}$, L. Østrem ${ }^{\mathrm{f}}$, \\ D. Reheul ${ }^{g}$, F. Volaire ${ }^{\mathrm{h}}$ \\ a Norwegian University of Life Sciences (NMBU), Faculty of Biosciences, Dept. of Plant Sciences, P.O. Box 5003, N-1432 Ås, Norway \\ b Department of Agricultural Sciences, Desertification Research Centre, University of Sassari, Viale Italia 39, 07100 Sassari, Italy \\ c Natural Resources Institute Finland (LUKE), Green technology, Halolantie 31A, 71750, Maaninka, Finland \\ ${ }^{\mathrm{d}}$ UMR Ecosystème Prairial, INRA, VetAgroSup, 63000 Clermont-Ferrand, France \\ e Norwegian Institute of Bioeconomy Research (NIBIO), Department of Grassland and Livestock, Holt, 9016 Tromsø, Norway \\ ${ }^{\mathrm{f}}$ Norwegian Institute of Bioeconomy Research (NIBIO), Department of Grassland and Livestock, Fureneset, 6967 Hellevik i Fjaler, Norway \\ g Ghent University, Faculty of Bioscience Engineering, Department of Plant Production, B-9000 Gent, Belgium \\ ${ }^{\text {h }}$ UMR 5175, Centre d'Ecologie Fonctionnelle et Evolutive, Université de Montpellier, Université Paul Valéry, EPHE, 1919 route de Mende, F-34293 Montpellier, France
}

\section{A R T I C L E I N F O}

\section{Keywords:}

Breeding

Grassland

Management

Persistence

Productivity

Seasonal stress

\begin{abstract}
A B S T R A C T
Climate change and its effects on grassland productivity vary across Europe. The Mediterranean and Nordic regions represent the opposite ends of a gradient of changes in temperature and precipitation patterns, with increasingly warmer and wetter winters in the north and increasingly warmer and drier summers in the south. Warming and elevated concentration of atmospheric $\mathrm{CO}_{2}$ may boost forage production in the Nordic region. Production in many Mediterranean areas is likely to become even more challenged by drought in the future, but elevated $\mathrm{CO}_{2}$ can to some extent alleviate drought limitation on photosynthesis and growth. In both regions, climate change will affect forage quality and lead to modifications of the annual productivity cycles, with an extended growing season in the Nordic region and a shift towards winter in the Mediterranean region. This will require adaptations in defoliation and fertilization strategies. The identity of species and mixtures with optimal performance is likely to shift somewhat in response to altered climate and management systems. It is argued that breeding of grassland species should aim to (i) improve plant strategies to cope with relevant abiotic stresses and (ii) optimize growth and phenology to new seasonal variation, and that plant diversity at all levels is a good adaptation strategy.
\end{abstract}

\section{Climate change and Nordic versus Mediterranean grasslands}

The most contrasting regions of Europe in terms of climate are the Mediterranean and the Nordic regions, representing a latitudinal gradient in temperature (Metzger et al., 2005). Within these regions, there are gradients in both oceanicity and precipitation. According to the environmental classification and stratification of Europe made by Metzger et al. (2005), the largest environmental zones in the Nordic region are the Alpine North and the Boreal zones, but in the southern part of this region there are also Nemoral, Atlantic North and Continental zones. There is a strong west to east gradient of decreasing precipitation in the Nordic region. The Mediterranean region of Europe has a complex pattern of environmental zones (Mediterranean South, Mediterranean North and Mediterranean Mountains), largely determined by temperature (Metzger et al., 2005). While forage production from grasslands are limited by cold and dark winters in the Nordic region, it is limited by hot and dry summers in the Mediterranean region. Across Europe, climate change could raise significant challenges for grassland-based food production and other ecosystem services provided by grasslands, but may also imply some opportunities. The observed and projected climate change differs between Northern and Southern Europe (Kovats et al., 2014, Table 1). The average temperature over land surface during $2002-2011$ was $1.3^{\circ} \mathrm{C}$ above the 1850-1899 average, with substantial differences between regions and seasons. In the Nordic region, both the observed and predicted warming is more rapid than the global average warming. Annual average temperatures have increased with more than $2{ }^{\circ} \mathrm{C}$ during 1847-2013, almost twice the global average increase, and both the observed and the predicted temperature increase is highest during late autumn, winter and spring (Uleberg et al., 2014; Mikkonen et al., 2015;

\footnotetext{
* Corresponding author

E-mail address: ashild.ergon@nmbu.no (Å. Ergon).
} 
Table 1

The main climatic changes and their effects in Nordic vs. Mediterranean grasslands during the growing season and the unfavorable season.

\begin{tabular}{|c|c|c|c|c|}
\hline \multirow[t]{4}{*}{ Growing season } & Current timing & $\begin{array}{l}\text { Nordic } \\
\text { April-early June to Mid-September-early November }{ }^{1}\end{array}$ & \multicolumn{2}{|l|}{$\begin{array}{l}\text { Mediterranean } \\
\text { October-June }\end{array}$} \\
\hline & $\begin{array}{l}\text { Predicted seasonal } \\
\text { changes }\end{array}$ & $\begin{array}{l}\text { 1) Extension of thermal growing season by } 1-3 \text { months by } \\
\text { the end of the century } 2,3 \\
\text { 2) Increase in temperature and precipitation } \\
\text { a,3-7 }\end{array}$ & \multicolumn{2}{|c|}{$\begin{array}{l}\text { 1) Growing season will shift towards winter }{ }^{17,18} \text { due to drier } \\
\text { summers and warmer winters } \\
\text { 2) Higher temperatures and more frequent droughts }{ }^{4,20-22}\end{array}$} \\
\hline & Effects on productivity & $\begin{array}{l}\text { 1) Increase in productivity if plant available water does not } \\
\text { become limiting } \\
\text { 2) Lengthening of growing season can be utilized mostly in } \\
\text { spring due to lack of light in late autumn } n^{8,9} \\
\text { 3) One extra cut per year in many regions }{ }^{1}\end{array}$ & \multicolumn{2}{|c|}{$\begin{array}{l}\text { 1) Increase in productivity when water is not limiting, higher } \mathrm{CO}_{2} \\
\text { concentration will limit yield reduction due to drought } \\
\text { stress }^{17,18,23}\end{array}$} \\
\hline & $\begin{array}{l}\text { Plant material and } \\
\text { breeding needs }\end{array}$ & $\begin{array}{l}\text { 1) More intra- and interspecific diversity, broader genetic } \\
\text { material with more response diversity }{ }^{10,11} \\
\text { 2) Higher regrowth capacity } \\
\text { 3) Maintenance of growth in water-saturated soils and } \\
\text { during dry spells }\end{array}$ & \multicolumn{2}{|c|}{$\begin{array}{l}\text { 1) More intra- and interspecific diversity }{ }^{24-26} \\
\text { 2) Utilization of cooler parts of the year for increased growth } \\
\text { 3) Maintenance of growth under moderate drought }\end{array}$} \\
\hline \multirow[t]{4}{*}{ Unfavorable season } & Current timing & $\begin{array}{l}\text { Nordic } \\
\text { Mid-September-early November to April-early June }{ }^{1}\end{array}$ & & $\begin{array}{l}\text { Mediterranean } \\
\text { June-early October }\end{array}$ \\
\hline & $\begin{array}{l}\text { Predicted seasonal } \\
\text { changes }\end{array}$ & \multicolumn{2}{|c|}{$\begin{array}{l}\text { 1) Shorter winters with more precipitation and higher temperatures }{ }^{4,5,7,12} \\
\text { 2) Delayed cold acclimation/growth cessation and earlier deacclimation/ } \\
\text { spring regrowth }{ }^{9} \\
\text { 3) Decrease or increase in snow cover, soil frost and ice encasement, } \\
\text { depending on temperature level, precipitation and interactions between } \\
\text { them }^{13-16}\end{array}$} & $\begin{array}{l}\text { 1) Longer summers with higher temperatures and } \\
\text { more frequent and severe droughts and heat } \\
\text { waves } 4,20,21 \\
\text { 2) Altered timing or conditions during critical } \\
\text { phases of life and growth cycles }{ }^{27-29}\end{array}$ \\
\hline & $\begin{array}{l}\text { Effects on } \\
\text { productivity }\end{array}$ & \multicolumn{2}{|c|}{$\begin{array}{l}\text { 1) Increased or decreased winter mortality due to higher or lower stress } \\
\text { levels and changes in growth cycle, plant } C \text { and } N \text { acquisition and use, } \\
\text { acclimation and deacclimation }{ }^{1,9,17}\end{array}$} & $\begin{array}{l}\text { 1) Decreased productivity or longer non- } \\
\text { productive dry season, higher summer } \\
\text { mortality }{ }^{17,18}\end{array}$ \\
\hline & $\begin{array}{l}\text { Plant material and } \\
\text { breeding needs }\end{array}$ & \multicolumn{2}{|c|}{$\begin{array}{l}\text { 1) More intra- and interspecific diversity, broader genetic material with } \\
\text { more response diversity }{ }^{10,11} \\
\text { 2) Utilize earlier spring and later autumn without losing ability to survive } \\
\text { winters }{ }^{9}\end{array}$} & $\begin{array}{l}\text { 1) More intra- and interspecific diversity }{ }^{24-26} \\
\text { 2) Stronger summer dormancy and active recovery } \\
\text { after drought in perennials }{ }^{30-32} \\
\text { 3) more persistent seed banks of annuals }{ }^{33-35}\end{array}$ \\
\hline
\end{tabular}

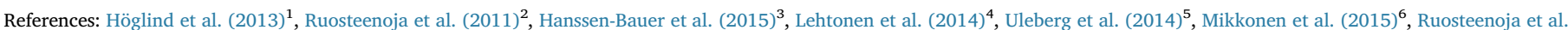

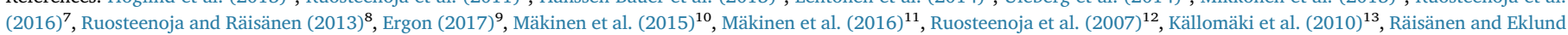

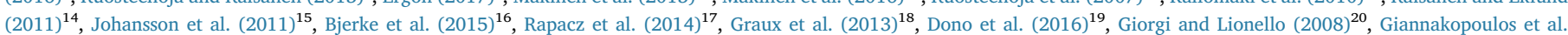

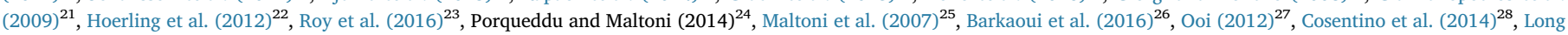
et al. $(2015)^{29}$, Volaire et al. $(2014)^{30}$, Norton et al. $(2016)^{31}$, Kallida et al. $(2016)^{32}$, Sulas $(2005)^{33}$, Salis et al. $(2012)^{34}$, Porqueddu et al. $(2016)^{35}$.

a change associated with high uncertainty.

Ruosteenoja et al., 2016). The length of the thermal growing season has increased with about 1-2 weeks during the last 30 years, and has been predicted to become 1-3 months longer by the end of the century as compared to the period 1971-2000 (Ruosteenoja et al., 2011; HanssenBauer et al., 2015). Annual precipitation in the Nordic region is predicted to increase considerably (up to around $20 \%$ relative to 1971-2000 in some regions) by the end of the century, with more frequent episodes of extreme precipitation, and especially during winter (Lehtonen et al., 2014; Hanssen-Bauer et al., 2015). In the Mediterranean region, the climate is expected to become warmer and drier, particularly in summer (Giorgi and Lionello, 2008; Giannakopoulos et al., 2009; Lehtonen et al., 2014). Winters are also expected to become warmer, but to a lesser extent than summers, while winter precipitation may vary between regions (Giorgi and Lionello, 2008; Giannakopoulos et al., 2009; Hoerling et al., 2012). Increased inter-annual variability in summer and winter precipitation, as well as in summer temperatures, is also expected (Giorgi and Lionello, 2008). Changes in atmospheric $\mathrm{CO}_{2}$ concentration, temperature and precipitation patterns are expected to affect plant productivity in a complex manner due to a set of mechanisms and interactions at different scales from the individual leaves to agroecosystems (Hatfield and Prueger, 2011; Xu et al., 2013). For grasslands, there are also important complicating factors such as plant competition and other plant-plant interactions, perennial growth habits, seasonal productivity patterns, and plant-animal interactions (Porter et al., 2014).

Grasslands comprise a variety of vegetation types and management systems (e.g. Allen et al., 2011; Huyghe et al., 2014; Peeters et al.,
2014). A distinction is made between temporary and permanent grasslands. Temporary grasslands, also termed forage crops, are regularly re-established (annually or at longer intervals), or constitute an element in a crop rotation. Permanent grasslands are grasslands that have either never been ploughed or not been ploughed for at least five to ten years (definitions vary). Permanent grasslands can range from natural and semi-natural (not managed by other means than grazing or mowing) to agriculturally improved permanent grasslands (i.e. improved by fertilization). Both temporary and permanent grasslands may be harvested by mowing (meadows), grazing (pastures) or a combination, and consist of perennial, biennial and/or annual forage species, mainly grasses and legumes. Overviews of grassland production in the Nordic and Mediterranean regions of Europe were recently given by Helgadóttir et al. (2014) and Porqueddu et al. (2016). Nordic grasslands are dominated by perennial grasses, with a few perennial legume species also present. Annual species are used only to a limited extent. There are both permanent and temporary grasslands, which are grazed or mown. Due to the lack of plant growth during winter, there is a strong reliance on harvested and conserved forage. In Mediterranean Europe, grasslands can be grazed from autumn to spring and may be mown in spring for hay production. Permanent grasslands can be dominated both by perennial and annual grasses, while temporary grasslands are often dominated by annual species. In summer, forage production can be completely or very limited by drought. Agro-silvopastoral systems are important in some areas. Annual and perennial grasses and legumes such as alfalfa (Medicago sativa L.) are to some extent cultivated as forage crops, which are sometimes irrigated. We 
here review the current research available related to the challenges and opportunities for forage production associated with changing climate in these two contrasting regions. We consider challenges and opportunities created by climate change in terms of forage productivity, forage quality and plant species composition (Section 2), while also assessing how utilization of plant traits and management practices could enable adaptation (Section 3). Although intimately linked to forage production, livestock production and the integration of mitigation and adaptation strategies is not within the scope of the present paper.

\section{What are the challenges and opportunities of climate change in Nordic versus Mediterranean grasslands?}

\subsection{Forage dry matter productivity}

In the Nordic region, the short growing season generally limits agricultural production (Peltonen-Sainio et al., 2009). Thus, longer growing season is favourable, especially in spring when water supply and solar radiation is optimal for growth. In a modelling study, Höglind et al. (2013) found 11\% increase in annual dry matter (DM) yields of timothy (Phleum pratense L.) in northern Europe in 2040-2065 as compared to 1960-1990, with the largest increases in the western regions which were less water-limited than the eastern regions. This study assumed that farmers adjusted the timing and number of harvests, and that nutrient conditions were optimal, but did not take the effect of elevated $\mathrm{CO}_{2}$ on growth into account. Elevated atmospheric $\mathrm{CO}_{2}$ concentration has the potential to increase photosynthetic rates and biomass production of $\mathrm{C}_{3}$ plants (Ainsworth and Long, 2005; Soussana and Lüscher, 2007). In a study of timothy and lucerne mixtures in eastern Canada, which did take the effect of elevated $\mathrm{CO}_{2}$ into account, 5-35\% increase in DM yield in 2020-2079 relative to 1971-2000 was estimated (Thivierge et al., 2016). This occurred despite an increase in the duration of periods when high temperatures or water shortages limited the productivity. However, there are large uncertainties in the predictions. In pure grass stands the positive effect of temperature and $\mathrm{CO}_{2}$ on yield may be limited by N (Leakey et al., 2009; Piva et al., 2013), and it may not be possible to utilize all of the extended thermal growing season. Although temperatures increase, the unique photoperiod in Northern latitudes remains unchanged. Short days and low inclination of incoming solar radiation in autumn can limit the amount of photosynthetically active radiation to the point that it becomes a restricting factor for growth, particularly at higher latitudes (Ruosteenoja and Räisänen, 2013; Uleberg et al., 2014; Virkajärvi et al., 2015).

There are many uncertainties regarding winter stresses in a future climate (Rapacz et al., 2014). The type and severity of winter stresses depends not only on the minimum temperature during winter, but also largely on the presence or absence of a snow cover, and on factors that control the cold acclimation status of the plants. Decrease in long-term mean snowpack has been predicted toward the end of the century, although individual snow-rich winters will still occur (Räisänen and Eklund, 2011). Thus, there will be shorter duration of snow cover and eventually snow-free winters in some regions now characterized by stable snow cover. On the other hand, increased precipitation in areas where temperatures remain below freezing can give longer-lasting snow cover in some areas (Johansson et al., 2011). Less snow cover can increase the occurrence, depth and duration of soil frost due to less insulation (Källomäki et al., 2010; Bjerke et al., 2015), and was shown to affect annual productivity of grasslands in Canada and Germany (Vankoughnett et al., 2016; Zeeman et al., 2017). There has been an increase in frequency of winter warming events in northern Norway, Sweden, and Finland during the last 50 years (Vikhamar-Schuler et al., 2016). This has led to increased numbers of melt-days during winter by 3-7 days per decade, and a further increase in such events are projected. The combination of increased precipitation in the autumn and winter, milder and unstable temperatures, and frozen soils, may lead to ice cover or waterlogging. The risk of winter damage is expected to increase east of the Baltic Sea, even for the winter hardy species timothy, while the risk of spring frost damage is predicted to increase in the western part of the Nordic area (Höglind et al., 2013). In winter, when solar irradiation is insufficient for photosynthesis in northern latitudes, the carbon-economy and survival of the plants becomes increasingly important when temperatures exceed $5{ }^{\circ} \mathrm{C}$ and respiration increases. On the other hand, if temperatures remain cool, shorter winters could leave more $\mathrm{C}$ and $\mathrm{N}$ reserves in spring, increasing survival and spring DM production (Jing et al., 2013; Piva et al., 2013). Higher temperatures in autumn will shift cold acclimation of the plants to a time when less light is available. This can have impacts on growth cessation and cold acclimation of plants (Østrem et al., 2014; Dalmannsdottir et al., 2017; Ergon, 2017), rendering them more vulnerable to winter stresses. In addition, waterlogged soils in combination with higher autumn temperatures have negative effects on cold acclimation of timothy (Jørgensen et al., 2016). Unstable winter temperatures and early springs can cause plants to de-acclimate, when there is still a risk of freezing (Jørgensen et al., 2010; Rapacz et al., 2014). The distribution of many weeds, pests and pathogens are limited to the north by harsh winters. With global warming, many of these species can be expected to spread northward (Jepsen et al., 2011; Juroszek and von Tiedemann, 2013; Svobodová et al., 2014).

More severe and frequent droughts leading to reduced productivity through both reduced growth and reduced persistence, is considered the major climate challenge for forage production in the Mediterranean region in the future. The direct effect of heat stress is not likely to be of the same importance in grasslands as in grain crops, where heat stress during certain stages of reproductive development can be detrimental for yields. In the Mediterranean region, water availability will often be more limiting for photosynthesis than the atmospheric $\mathrm{CO}_{2}$ concentration, but $\mathrm{CO}_{2}$ concentration still has important effects due to interactions with temperature and drought. Elevated $\mathrm{CO}_{2}$ can partly compensate for the reduced $\mathrm{CO}_{2}$ influx through stomata under moderate drought (Ainsworth and Long, 2005; Soussana et al., 2010). Consequently, elevated $\mathrm{CO}_{2}$ enhances biomass production and improves water relations under drought (Clark et al., 1999). In addition, elevated $\mathrm{CO}_{2}$ contributes to water sparing (reduced transpiration due to less stomatal opening) during periods when sufficient water is available, leaving more water for later in the season, when the water reserves might otherwise be exhausted (Morgan et al., 2004).

In Mediterranean Europe, the productivity of rainfed grasslands is limited during the dry summer. Changes in the seasonal patterns of temperature and precipitation are likely to shift productivity further towards cooler and wetter parts of the year. Projections of climate change impact on grassland productivity (Graux et al., 2013) indicated that summer yields may be reduced in Mediterranean France in the far future (2070-2099). However, in this study higher yields were predicted in autumn, winter and spring due to a combined effect of higher temperatures and $\mathrm{CO}_{2}$ levels, leading to an overall increase in productivity. In line with this, Dono et al. (2016), modelling productivity of semi-natural grasslands dominated by self-reseeding annual species (no summer production) in the near future (2020-2030) in Sardinia, Italy, predicted decreased spring yields and higher autumn yields due to increased temperature and increased rainfall occurrence in October. In the same study, irrigated annual ryegrass crops were predicted to have increased yields in the near future. Model-based studies are affected by uncertainties and assumptions and, as Graux et al. (2013) pointed out, their study neither accounted for a possible increase in mortality of perennials during summer droughts, nor climate change-induced changes in species composition, both factors that may have importance in grasslands.

In summary, grassland productivity can be expected to increase in the Nordic region, and shift towards winter in the Mediterranean region, except on relatively moist or irrigated land (Table 1, Fig. 1). 
$\begin{array}{lll}\text { Increased } \\ \text { (A) Nordic } & \text { temperature } & \text { Mield } \\ \text { precipitation }\end{array}$

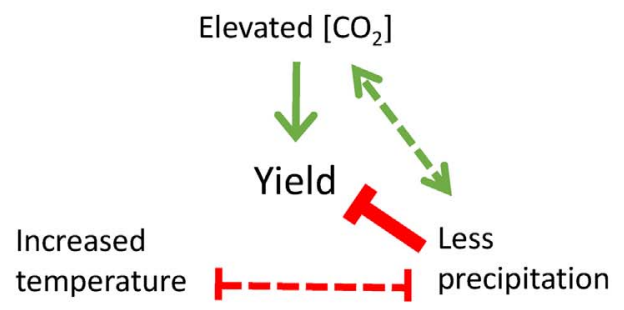

(B) Mediterranean dry/hot

\section{(C) Mediterranean less dry/less hot}

Fig. 1. Effects of climate change on forage production. Temperature, atmospheric $\left[\mathrm{CO}_{2}\right]$ and precipitation can all affect grassland yields (positive effects indicated by pointed arrows and negative effects indicated by blunted arrows). In addition, they interact (indicated by broken lines): elevated $\left[\mathrm{CO}_{2}\right]$ improves drought tolerance under moderate drought due to a decrease in stomatal conductance, and higher temperatures promotes drought by increasing evapotranspiration, while drought reduces evaporative cooling and exacerbates heat stress. (A) In the Nordic region increased temperature and elevated $\left[\mathrm{CO}_{2}\right]$ will increase grassland productivity during the growing season. More precipitation will probably have a positive effect on productivity in many areas, but can also have negative effects through water logging, soil compaction and nutrient leakage. In the Mediterranean region, the negative effect of less precipitation will override the positive effect of elevated $\left[\mathrm{CO}_{2}\right]$ during summer and in dry regions (B), but during the rest of the year, and in less dry areas, the positive effects of increased temperature and elevated $\left[\mathrm{CO}_{2}\right]$ will override the negative effect of less precipitation (C).

\subsection{Forage quality and species composition}

Climate change may affect forage quality in different ways. Higher temperatures lead to earlier stem elongation, a faster rate of decline in cell wall digestibility of both vegetative and reproductive tillers during aging, and hence faster decline in the digestibility of forages (Groot et al., 2003; Thorvaldsson et al., 2007; Bertrand et al., 2008; Bloor et al., 2010; Jing et al., 2013). In addition, higher standing biomass is associated with higher stem-to-leaf proportions and lower digestibility, at least in timothy (Bélanger and McQueen 1998; Bélanger et al., 2001), and thus climate change may lead to lower or higher digestibility through its effect on growth rate, stand density and competition for light. The effects of phenological development and standing biomass can largely be compensated by changes in defoliation regimes and fertilization (discussed below). Climate change may also affect forage quality through effects on species composition. Elevated $\mathrm{CO}_{2}$ tends to increase the competitive ability of legumes in legume-grass mixtures, if the legumes are not limited by minerals such as phosphorous (reviewed by Lüscher et al., 2004; Soussana and Lüscher, 2007; Soussana et al., 2010). This may compensate for the slight decrease in protein content of grasses at elevated $\mathrm{CO}_{2}$ (Soussana and Lüscher, 2007; Dumont et al., 2015). Dumont et al. (2015), in their meta-study of climate change effects on forage quality, found that elevated $\mathrm{CO}_{2}$ did not affect digestibility, but increased the total non-structural carbohydrate content by an average of $25 \%$ and decreased $\mathrm{N}$ content by $8 \%$, reflecting the shift in the C:N-ratio of the environment. $\mathrm{N}$ content increased with increasing drought level, and unlike other sites, a decrease in herbage $\mathrm{N}$ concentration in response to elevated $\mathrm{CO}_{2}$ was not found at Mediterranean sites. The authors suggested that this could be due both to water limitation on growth, and changes in species composition (higher legume proportion), leading to higher concentration of $\mathrm{N}$ in the forage. In some Mediterranean regions, e.g. in semi-arid Italy, semi-natural grasslands are dominated by annual species that are maintained by seed banks (Cosentino et al., 2014). The species composition in these grasslands varies between years, depending on previous seed production, dormancy and germination. These are all processes strongly influenced by climatic conditions such as temperature and moisture, and therefore most likely affected by climate change (Ooi, 2012; Cosentino et al., 2014; Long et al., 2015).

\section{How to address these challenges and opportunities?}

Grassland management targets an optimal balance between forage yield, forage quality, yield stability and persistence (plant survival or reproduction). This can be achieved through a suitable choice of plant material, optimization of the defoliation and fertilization strategies, irrigation, drainage, soil management, control of unwanted organisms, and renovation or re-establishment of the grassland.

\subsection{Choice of plant material}

Choosing the best species and mixtures for sown grasslands can be a way to meet challenges and utilize opportunities raised by climate change. A harsh winter climate is the strongest limiting factor determining which perennial species can be cultivated in the Nordic region. Although there is considerable uncertainty regarding winter survival in the future, a longer growing season and milder winters may increase the prospective for using species and cultivars with higher yield potential and feeding value. Currently, winter hardy species such as timothy, meadow fescue (Schedonorus pratensis Huds. syn. Festuca pratensis Huds.) and red clover (Trifolium pratense L.), are widely used (Helgadóttir et al., 2014). Species like perennial ryegrass (Lolium perenne L.) and festulolium ( $\times$ Festulolium Aschers. et Graebn.) are used in the southern Nordic area, and are of increased interest for the future climate also further north because of their high production capacity throughout the growing season as well as high nutritive value ( $\varnothing$ strem 
et al., 2013). Including deep-rooted drought tolerant species like tall fescue (S. arundinaceus Schreb. syn. F. arundinacea Schreb.), fescue type festulolium, cocksfoot (Dactylis glomerata L.), red clover and lucerne in the mixtures can be a strategy to prevent yield reduction during drought periods. Tall fescue has a better nitrogen uptake, nitrogen use efficiency and water use efficiency, and a yield potential which is up to $50 \%$ higher than perennial ryegrass in dry periods, most probably owing to its deeper rooting system (Cougnon, 2013; Cougnon et al., 2017). In addition, it can tolerate poorly drained soils (Barnes et al., 2003). However, the digestibility and animal preference is lower than in perennial ryegrass (Cougnon et al., 2014). Cultivation of whole crop maize (Zea mays L.) has increased during the last decades and the expected climate changes will further promote this development, at least in southern parts of the Nordic region (Elsgaard et al., 2012). This could be compatible with an increased use of legumes and total mixed ratio feeding strategies, where high protein forages can be complemented with low protein but high energy components, and thereby influencing what type of grasslands will be cultivated.

A wide range of annual forage species showing adaptability to Mediterranean climate conditions are currently available in the market (e.g. oat (Avena sativa L.), italian ryegrass (L. multiflorum Lam.), crimson clover (T. incarnatum L.), egyptian clover (T. alexandrinum L.), common vetch (Vicia sativa L.)) (Annicchiarico et al., 2013; Porqueddu et al., 2016). Despite an increasing use of annual self-reseeding species (mainly subterranean clover (T. subterraneaum L.) and Medicago spp.) for pasture improvement in dry environments (Porqueddu and Gonzalez, 2006), cultivars available in the seed market have often proved to be poorly adapted to the climatic conditions and management systems of Mediterranean Europe (Sulas, 2005; Salis et al., 2012; Porqueddu et al., 2016). Native genotypes of these species (e.g., rigid ryegrass (L. rigidum Gaud.) and burr medic (M. polymorpha L.)) have been selected (Porqueddu, 2001; Franca et al., 2005), but not adopted by the seed industry in Europe so far. Perennial forages such as tall fescue or cocksfoot can be a valuable alternative to annuals, if they can survive across successive summer droughts. Although most of the temperate origin cultivars available on the market are not drought persistent in Mediterranean areas (Lelièvre and Volaire, 2009), a few cultivars with summer dormancy (Volaire and Norton, 2006) can tolerate severe successive droughts and survive in environments with annual rainfall as low as $300 \mathrm{~mm}$ (Annicchiarico et al., 2011; Pecetti et al., 2009, 2011). Under chronic water shortages, perennial forage species have a number of advantages in comparison to the predominantly used annual species including (i) fewer inputs with less field preparation and fertilizer requirement, (ii) year-around soil cover reducing the risk of intense soil erosion, (iii) optimal use of water throughout all seasons, thus enhancing forage production in particular in autumn when cereals and annual species are not yet established and (iv) greater flexibility because of the multiple uses of these species (grazing, hay, silage). Therefore, perennial species are an excellent alternative to annual species, contributing to reduced production costs, to halt rangeland degradation and overall to confer greater security to rain-fed agricultural systems (Lelièvre and Volaire, 2009; Volaire et al., 2016). Cultivars of bulbous canary-grass (Phalaris aquatica L.) and tall fescue that express summer dormancy play an increasing role in eastern Australia and the semi-arid environment of the Southern Great Plains in the USA, and can be used in regions with down to about 550-500 mm precipitation per year (Oram and Lodge, 2003; Malinowski et al., 2005, 2009; Norton et al., 2016). Such cool season grasses were also found to be quite productive and successful in south-west Australia (Rogers et al., 1976; Biddiscombe et al., 1977) although until recently they have been poorly adopted by the seed industry. The association of summer dormant grasses and Mediterranean type alfalfa, combining the dehydration tolerance of the grass and the dehydration avoidance of the legume provides high functional complementarity for water use in summer and is advocated for drought prone areas (Volaire et al., 2016).

Unstable conditions with large variation in weather within and between seasons increase uncertainty in forage production. Diversity among responses to critical weather factors improves resilience at both sward and farm level (Mäkinen et al., 2015). Seed and variety mixtures with components that have both desired traits and complementary niches can exploit temporal and spatial variation in environmental conditions, and be more stable and robust compared to monocultures or simple mixtures. Using mixtures is therefore considered a key strategy to maintain production in unpredictable and unstable environments (Maltoni et al., 2007; Volaire et al., 2014; Lüscher et al., 2014). Species and variety mixtures also tend to be more stable in forage quality than pure stands of one species (Sleugh et al., 2000; Sanderson, 2010; Ergon et al., 2017), and therefore allows for some flexibility in harvest times, which is desirable in rainy summers in the Nordic region. It may be possible to design optimized mixture compositions based on detailed experiments (Goslee et al., 2013). For example, mixtures of summerdormant and summer-active perennial species may provide stable pastures exploiting available soil moisture throughout the year in some Mediterranean regions (Norton et al., 2016). Similarly, grass-legume mixtures including both annuals and perennials proved to achieve higher yields and utilize a longer period for growth than pure stands, under dry Mediterranean conditions (Porqueddu and Maltoni, 2007; Maltoni et al., 2007). However, when a single environmental factor is dominant, yield and survival may depend largely on a specific trait rather than on functional diversity. For example, under severe summer water deficit, rooting depth enhanced water uptake and resilience of grass communities irrespectively of the level of species diversity in the communities (Barkaoui et al., 2016). Including $\mathrm{N}$-fixing legumes in mixtures has several advantages, and can facilitate a better exploitation of elevated atmospheric $\mathrm{CO}_{2}$ concentration (Lüscher et al., 2004, 2014). However, since legumes require relatively high amounts of $\mathrm{K}$ and $\mathrm{P}$, nodulation and $\mathrm{N}$ fixation may become limited by low nutrient supply and high or low temperatures (Nesheim and Boller, 1991; Irigoyen et al., 2014), and the conservation of legume forage can be challenging, particularly in a wet Nordic climate.

\subsection{Breeding for the future climate}

In order to meet the challenges and utilize the opportunities that climate change will bring, the plant material we cultivate should (i) exhibit growth cycles that better fit the new seasonal climate patterns, (ii) be able to cope with relevant stresses and have the right balance between growth potential, nutritive value and stress tolerance, and (iii) have the phenotypic plasticity or genetic diversity within populations that ensures yield stability under variable and unpredictable conditions.

The annual recurrent periods of winter stresses or summer droughts have led to the evolution of seasonal acclimation and de-acclimation processes regulating the level of resistance to seasonal stresses in perennial grasses (Laude, 1953; Volaire and Norton, 2006; Preston and Sandve, 2013). These processes, which are largely regulated by temperature and photoperiod, correlate with changes in growth, reproductive development and dormancy status (Preston and Sandve, 2013; Norton et al., 2009; Gillespie and Volaire, 2017), and latitudinal clines in responses to temperature and photoperiod have been described (Cooper, 1964). With global warming, there will be new combinations of temperature and photoperiod. This is particularly the case in the north where photoperiod changes dramatically during the course of a year. In order to utilize a longer growing season in Nordic Europe, and a shift in the growing season in Mediterranean Europe, we need species and varieties with temperature and photoperiod responses conferring an annual growth pattern that optimizes growth during the favourable part of the year and survival during the cold Nordic winter or dry Mediterranean summer (Ergon, 2017). Resistance to winter stresses are still likely to be of high importance in the Nordic region in the future (see Section 1). Plants encounter many stresses during winter: freezing, anoxia due to ice encasement or water-saturated soils, soil movements due to freeze-thaw cycles, winter pathogens, starvation 
and dehydration due to frozen soils. Specific resistance mechanisms to these stresses exist, but they are also largely interconnected through genetics and physiology. Central to winter survival is proper cold acclimation in autumn and sufficient maintenance of a cold acclimated state in spring. During cold acclimation, leaf elongation ceases, a number of stress responses are elicited, and organic reserves accumulate. Both cold acclimation in autumn and deacclimation in spring are mainly controlled by temperature. However, light is also important in at least three different ways: (i) high irradiance combined with low temperature increases the photosystem II excitation pressure, eliciting signalling pathways leading to cold acclimation, (ii) light is the energy source for the accumulation of organic reserves, and (iii) photoperiod is a developmental signal influencing growth, cold acclimation and deacclimation. Due to these reasons, the shift of cold acclimation and deacclimation into shorter photoperiods may affect the ability of plants to cope with winter stresses (Dalmannsdottir et al., 2017). A more detailed and quantitative understanding of interactions between temperature and light on winter survival in different species is needed. Breeding activities may need to focus on adjusting the timing of growth cessation and cold acclimation in autumn, and the opposite process in spring, to new temperature and photoperiod combinations. For example, at high latitudes, perennial ryegrass and festulolium tend to cease growth in autumn too late for sufficient cold acclimation (Østrem et al., 2014). It will however, be necessary to manage the trade-off between optimal timing with respect to winter survival, and utilization of the longer growing season to increase production (Ergon, 2017). In order to utilize the potential for higher productivity in the north, there is also a need for strong regrowth capacity and tolerance to more frequent harvesting or grazing. For timothy, the priorities would likely be to improve tolerance to harvesting and grazing, better regrowth capacity and spring growth. Perennial ryegrass needs better winter survival, particularly improved timing of growth cessation and cold acclimation, as well as resistance to psycrophilic pathogenic fungi (Abdelhalim et al., 2016), while for tall fescue, work is ongoing to combine the high yield and drought tolerance with an acceptable digestibility and animal preference (Humphreys et al., 2012; Helgadóttir et al., 2014; Cougnon et al., 2015; Fariaszewska et al., 2016).

Drought escape (i.e. when plants survive the dry summer as seeds; Long et al., 2015) and hardseededness (which allows a more persistent seed bank; Taylor, 2005) are the main adaptive strategies of annual species in Mediterranean grasslands. Based on the predicted changes in precipitation, with an overall reduced growth period in the driest Mediterranean regions, annual species will need earlier seed maturation for reliable seed set in shorter growing seasons, as well as mechanisms (i.e. regulation of seed dormancy and germination) ensuring the presence of a seedbank under the expected seasonal patterns of temperature and water availability (Porqueddu et al., 2016). A low requirement for dormancy release gives the potential for early germination and higher yield, but at the risk of seedling mortality due to false breaks. Given the uncertainty and the expected climatic variability, intra- and interspecific variation in regulation of dormancy release in cultivars and seed mixtures appears to be a good strategy. In the past, breeding efforts in tall fescue and cocksfoot have mainly been directed towards use in temperate areas with summer active material that are short lived under drought, and there are therefore very few cultivars adapted to severe drought currently available in southern Europe (Lelièvre and Volaire, 2009). Persistence during severe drought is governed by mechanisms different from those conferring resistance to moderate droughts (Milbau et al., 2005; Volaire et al., 2009). Plants with responses resulting in resistance under moderate drought and maintenance of shoot growth have to either avoid or tolerate leaf dehydration. At moderate drought, the maintenance of biomass production can be achieved primarily by maximizing soil water capture while maintaining stomatal gas exchange and transpiration (Blum, 2009). A deep root system with a high density of roots at depth (Carrow, 1996; Wasson et al., 2012; White and Snow, 2012) and maintenance of leaf area, leaf relative water content, leaf cell turgor and photosynthetic capacity (Morgan, 1988; Serraj and Sinclair, 2002) are traits that are associated with high yield in water-limited environments. Plant responses resulting in survival under severe drought, however, are mainly associated with growth cessation, dehydration avoidance and tolerance occurring in young tissues including basal meristematic tissues. When conditions improve, the surviving meristems can generate new leaves if the adult leaves are dead (Van Peer et al., 2004; Zwicke et al., 2015). In some species and genotypes from very dry areas, survival of basal meristematic tissues is achieved through summer dormancy (Volaire and Norton, 2006). In these plants, photoperiod and temperature induce (even under irrigation) cessation or reduction of shoot growth, various degrees of foliage senescence and a dehydration tolerance of meristems. The reduction in leaf tissue reduces total plant water loss (Gepstein, 2004; Munne Bosch and Alegre, 2004). A minimum water supply to the meristematic tissues is maintained (Karcher et al., 2008; McWilliam and Kramer, 1968; Volaire and Lelievre, 2001), and high concentrations of fructans and dehydrins contribute to osmoregulation and membrane stabilisation of these tissues (Hincha et al., 2000, 2002). High carbohydrate reserves are associated with superior plant resilience and recovery after severe drought (Boschma et al., 2003). Thus, to interpret low leaf water potential or high foliage senescence as responses associated with drought sensitivity and poor adaptation may be correct if maintained production under drought is the target, but highly misleading if drought survival during severe drought is the focus. Making the distinction between the responses of mature and young meristematic tissues is crucial when analysing the strategies of perennial grasses to contrasting drought intensities. It may be possible to combine drought resilience of perennial forage species with high biomass productivity in rainy seasons, as recently shown by crossing summer dormant with summer active and highly productive genotypes of cocksfoot (Kallida et al., 2016). Breeding programs are now starting to focus on the improvement of drought survival instead of targeting the maintenance of growth under moderate drought (Volaire et al., 2014). A broadening of the gene pools of most of the currently used species is probably necessary (Mäkinen et al., 2016), and future breeding, irrespective of crop species, demands efficient ways to incorporate wild adapted genetic resources and exotic material into the current breeding base (Helgadóttir et al., 2014). As argued above, the use of forage legumes has many advantages including nitrogen fixation, utilization of elevated $\mathrm{CO}_{2}$ and improvement of forage quality. In spite of this, there are only a few species used in the Nordic region, and the breeding efforts in the Mediterranean region have been limited. Many annual and perennial legume species, and their rhizobial symbionts, have been collected and developed into varieties and rhizobial strains now widely used in Mediterranean climates in Australia (Nichols et al., 2012). This suggests that varieties of a larger number of legume species could also be developed for use in different regions of Europe. Interestingly, although the Nordic and Mediterranean regions of Europe represent very different climates, there is some common ground in the adaptation of perennial grassland species to these climates: (i) seasonal regulation of growth and dormancy or quiescence, whether it is the winter or the summer that needs to "be survived", are likely to be regulated by similar molecular signalling systems responding to temperature and photoperiod (Gillespie and Volaire, 2017; Ergon, 2017), and (ii) tolerance of the tissue to seasonal stresses, whether it is freezing or drought, is partly based on the same mechanisms, both regarding induction of tolerance and the protective mechanisms themselves (Dolferus, 2014).

\subsection{Adapting grassland management}

The expected increase in rate of phenological development, and in some cases productivity, requires adaptation of defoliation and fertilization regimes. Moreover, in grasslands, the constraints on utilization of the $\mathrm{CO}_{2}$ fertilizing effect caused by photosynthetic acclimation can largely be overcome through defoliation (maintaining sink strength) 
and use of legumes (maintaining $\mathrm{N}$ availability), provided that there are sufficient amounts of water and other nutrients available (Soussana and Hartwig, 1996; Rogers et al., 1998; Picon-Cochard et al., 2004). Höglind et al. (2013) predicted that the earlier spring and higher temperatures would allow for one more cut per growing season in Northern Europe during the future period 2040-2065 compared to 1961-1990. In an attempt to reduce costs linked to an extra cut, farmers may decide to increase grazing. However, as $\mathrm{N}$ use efficiency of swards can be considerably lower under grazing compared to cutting (Nevens and Reheul, 2003), and as climate change is expected to create a higher potential for leaching in grazed grassland compared to cut grassland (Saarijärvi et al., 2004; Stuart et al., 2011), $\mathrm{N}$ fertilization has to be judiciously adjusted to prevailing management practices and climatic conditions in grazed systems to avoid excessive $\mathrm{N}$ leaching. In the current Nordic climate, excessive precipitation frequently causes problems with farm operations (Peltonen-Sainio et al., 2009; Olesen et al., 2011). Increased precipitation and waterlogged soils could make establishment of new leys, application of fertilizer, and harvesting challenging in some years, and is likely to increase nutrient runoff during winter (Saarijärvi et al., 2007; Edwards et al., 2007; Deelstra et al., 2011). With increased precipitation levels, care is needed to minimize soil compaction during farm operations, and maintain or improve drainage systems, particularly on some soil types (Rivedal et al., 2016). In the driest Mediterranean semi-natural grasslands dominated by annual species, grazing by livestock is recognized as the main driver influencing vegetation dynamics, species diversity and grassland productivity (Köchy et al., 2008; Carmona et al., 2012; Sternberg et al., 2015), and thus needs to be managed carefully, e.g. through the use of flexible stocking (Pahl et al., 2016). Similarly, the persistence of perennial forage species during a severe drought is affected by the defoliation regime in spring (Boschma et al., 2003) which can be detrimental if too intense, to the accumulation of water soluble carbohydrates ensuring drought survival of meristematic tissues (Volaire, 1994; Volaire and Gandoin, 1996). The exploitation of alternative forage resources in wooded grasslands could be a strategy to cope with the foreseen reduced pasture production (Moreno and Pulido, 2009; Del Prado et al., 2014). Such alternative forages may include tree leaves and shrubs, which can alleviate feed shortages, or even fill feed gaps in the winter and especially in the summer in small-scale livestock farms in dry to semi-arid climates (Papanastasis et al., 2008).

\section{Conclusions and perspectives for research priorities}

Climate change can increase grassland productivity due to higher temperatures, longer growing seasons and higher $\mathrm{CO}_{2}$ concentration, if there is sufficient amount of water available. However, water limitation will occur increasingly, particularly in the Mediterranean region during summer. Water limitation of forage production can to some extent be alleviated by higher $\mathrm{CO}_{2}$ concentration, which increases the water use efficiency, and by a shift in productivity towards the cooler part of the year in Mediterranean climates. The effect of climate change on plant winter survival in the Nordic region is difficult to predict due to interactions between temperature and snow cover on winter stress levels, and the interactions between temperature and light factors on cold acclimation and deacclimation processes. Other uncertainties regarding increased forage production in the Nordic region in the future climate includes water saturated soils and soil compaction, practical problems with cultivation and harvesting, and increasing occurrence of weeds, pests and diseases. Climate change can affect forage quality in several ways in both Nordic and Mediterranean regions through its effects on plant growth and development as well as species composition.

In the face of unstable and uncertain climatic conditions, a high diversity of cultivated forage species, high intraspecific genetic diversity, and the use of species and variety mixtures can enhance productivity and resilience of grasslands. In both the Mediterranean and Nordic regions, climate change will lead to changes in the annual growth patterns of grassland species (both growth rates and timing of growth), prompting adaptations of fertilization and defoliation regimes (timing and intensity). Breeding and research efforts should be stimulated towards (i) improving plant strategies to cope with relevant stresses in appropriate ways (e.g. maintenance of growth under moderate stress and survival under severe stress), (ii) optimizing the regulation of growth so that it fits new seasonal climate and defoliation patterns (e.g. increase growth potential during the cooler part of the year in the Mediterranean region or during spring in the Nordic region, and improve regrowth capacity after defoliation in the Nordic region), and (iii) utilizing plant diversity at all levels (e.g. develop mixtures with inter- and intraspecific variation in responses to climatic variables).

\section{Acknowledgements}

Funding: This work was supported by Norwegian Research Council (grant no. 225330), FACCE-JPI, European Agricultural Fund for Rural Development (grant no. 10640) and Fram Centre, Norway (grant no. 362208).

\section{References}

Abdelhalim, M., Rognli, O.A., Hofgaard, I., Østrem, L., Tronsmo, A.M., 2016. Snow mould resistance under controlled conditions and winter survival in the field in populations of perennial ryegrass, meadow fescue and festulolium are partly dependent on ploidy level and degree of northern adaptation. Can. J. Plant Sci. 96, 579-589. http://dx. doi.org/10.1139/CJPS-2015-0259.

Ainsworth, E.A., Long, S.P., 2005. What have we learned from 15 years of free-air CO2 enrichment (FACE)? A meta-analytic review of the responses of photosynthesis, canopy properties and plant production to rising CO2. New Phytol. 165, 351-372.

Allen, V.G., Batello, C., Berretta, E.J., Hodgson, J., Kothmann, M., Li, X., McIvor, J. Milne, J., Morris, C., Peeters, A., Sanderson, M., 2011. An international terminology for grazing lands and grazing animals. Grass Forage Sci. 66, 2-28. http://dx.doi.org/ 10.1111/j.1365-2494.2010.00780.x.

Annicchiarico, P., Pecetti, L., Bouzerzour, H., Kallida, R., Khedim, A., Porqueddu, C., Simões, N.M., Volaire, F., Lelièvre, F., 2011. Adaptation of contrasting cocksfoot plant types to agricultural environments across the Mediterranean basin. Environ. Exp. Bot. 74, 82-89. http://dx.doi.org/10.1016/j.envexpbot.2011.05.002.

Annicchiarico, P., Peccetti, L., Abdelguer, F.I.A., Bouzerzour, H., Kallida, R., 2013. Optimal forage germplasm for drought-prone mediterranean environments. Field Crops Res. 148, 9-14.

Bélanger, G., McQueen, R.E., 1998. Analysis of the nutritive value of timothy grown with varying N nutrition. Grass Forage Sci. 53, 109-119.

Bélanger, G., Michaud, R., Jefferson, P.G., Tremblay, G.F., Brégard, A., 2001. Improving the nutritive value of timothy through management and breeding. Can. J. Plant Sci. $81,577-585$.

Barkaoui, K., Roumet, C., Volaire, F., 2016. Mean root trait more than root trait diversity determines drought resilience in native and cultivated Mediterranean grass mixtures Agriculture. Ecosyst. Environ. 231, 122-132.

Barnes, R.F., Nelson, C.J., Collins, M., Moore, K.J., 2003. Forages -an Introduction to Grassland Agriculture Vol. 1 Blackwell Publishing ISBN-13: 978-0-8138-0424-7.

Bertrand, A., Tremblay, G.F., Pelletier, S., Castonguay, Y., Belanger, G., 2008. Yield and nutritive value of timothy as affected by temperature, photoperiod and time of harvest. Grass Forage Sci. 63, 421-432. http://dx.doi.org/10.1111/j.1365-2494.2008. 00649.x.

Biddiscombe, E.F., Rogers, A.L., R.A;1, Maller, 1977. Summer dormancy, regeneration and persistence of perennial grasses in south-western Australia. Aust. J. Exp. Agric. Anim. Husb. 17, 795-801.

Bjerke, J.W., Tømmervik, H., Zielke, M., Jørgensen, M., 2015. Impacts of snow season on ground-ice accumulation, soil frost and primary productivity in a grassland of subArctic Norway. Environ. Res. Lett. 10, 095007. http://dx.doi.org/10.1088/17489326/10/9/095007.

Bloor, J.M.G., Pichon, P., Falcimagne, R., Leadley, P., Soussana, J.-F., 2010. Effects of warming, summer drought, and $\mathrm{CO} 2$ enrichment on aboveground biomass production, flowering phenology, and community structure in an upland grassland ecosystem. Ecosystems 13, 888-900. http://dx.doi.org/10.1007/s10021-010-9363-0.

Blum, A., 2009. Effective use of water (EUW) and not water-use efficiency (WUE) is the target of crop yield improvement under drought stress. Field Crops Res. 112, 119-123.

Boschma, S.P., Hill, M.J., Scott, J.M., Rapp, G.G., 2003. The response to moisture and defoliation stresses, and traits for resilience of perennial grasses on the Northern Tablelands of New South Wales, Australia. Aust. J. Agric. Res. 54, 903-916.

Carmona, C.P., Azcárate, F.M., Bello, F., Ollero, H.S., Lepš, J., Peco, B., 2012 Taxonomical and functional diversity turnover in Mediterranean grasslands: inter actions between grazing, habitat type and rainfall. J. Appl. Ecol. 49, 1084-1093.

Carrow, R.N., 1996. Drought avoidance characteristics of diverse tall fescue cultivars. Crop Sci. 36, 371-377.

Clark, H., Newton, P.C.D., Barker, D.J., 1999. Physiological and morphological responses to elevated $\mathrm{CO} 2$ and a soil moisture deficit of temperate pasture species growing in an 
established plant community. J. Exp. Bot. 50, 233-242.

Cooper, J.P., 1964. Climatic variation in forage grasses. I. Leaf development in climatic races of Lolium and Dactylis. J. Appl. Ecol. 1, 45-61.

Cosentino, S.L., Porqueddu, C., Copani, V., Patanè, C., Testa, G., Scordia, D., Melis, R., 2014. European grasslands overview: mediterranean region. Grassland Sci. Eur. 19, 41-56.

Cougnon, M., Baert, J., Reheul, D.1, 2014. Dry matter yield and digestibility of five cool season forage grass species under contrasting N fertilizations. Grassland Sci. Eur. 19, 175-177.

Cougnon, M., Shahidi, R., Struyf, E., Van Waes, C., Reheul, D., 2015. Silica content, leaf softness and digestibility in tall fescue (Festuca arundinacea Schreb.). In: RoldánRuiz, I., Baert, J., Reheul, D. (Eds.), Breeding in a World of Scarcity. Springer Dordrecht, pp. 277-281.

Cougnon, M., De Swaef, T., Lootens, P., Baert, J., De Frenne, P., Shahidi, R., Roldàn-Ruiz, I., Reheul, D., 2017. In situ quantification of forage grass root biomass, distribution and diameter class under two N fertilization rates. Plant Soil 411, 409-422.

Cougnon, M., 2013. Potential in Mixed Swards and Breeding of Tall Fescue. Doctoral Thesis. Ghent University.

Dalmannsdottir, S., Jørgensen, M., Rapacz, M., Østrem, L., Larsen, A., Rognli, O.A., 2017. Cold acclimation in warmer extended autumns impairs freezing tolerance of perennial ryegrass (Lolium perenne L.) and timothy (Phleum pratense L.). Physiol. Plant. 160, 266-281.

Deelstra, J., Øygarden, L., Buseth-Blankenberg, A.G., Eggestad, H.O., 2011. Climate change and runoff from agricultural dominated catchments in Norway. Int. J. Clim. Change Strat. Manage. 3, 345-360.

Del Prado, A., van den Pol-van Dasselaar, Chadwick, D., Misselbrook, T., Sandars, D., Audsley, E., Mosquera-Losada, M.R., 2014. Synergies between mitigation and adaptation to Climate Change in grassland-based farming systems. Grassland Sci. Eur. 19, 61-74.

Dolferus, R.1, 2014. To grow or not to grow: a stressful decision for plants. Plant Sci. 229, 247-261. http://dx.doi.org/10.1016/j.plantsci.2014.10.002.

Dono, G., Cortignani, R., Dell'Unto, D., Deligios, P., Doro, L., Lacetera, N., Mula, L., Pasqui, M., Quaresima, S., Vitali, A., Roggero, P.P., 2016. Winners and losers from climate change in agriculture: insights from a case study in the Mediterranean basin. Agric. Syst. 147, 65-75. http://dx.doi.org/10.1016/j.agsy.2016.05.013.

Dumont, B., Andueza, D., Niderkorn, V., Lüscher, A., Porqueddu, C., Picon-Cochard, C., 2015. A meta-analysis of climate change effects on forage quality in grasslands: perspectives for mountain and Mediterranean areas. Grass Forage Sci. 70 293-254.

Edwards, A.C., Scalenghe, R., Freppa, M., 2007. Changes in the seasonal snow cover of alpine regions and its effect on soil processes: a review. Quat. Int. 162, 172-181.

Elsgaard, L., Børgesen, C.D., Olesen, J.E., Siebert, S., Ewert, F., Peltonen-Sainio, P., Rötter, R.P., Skjelvåg, A.O., 2012. Shifts in comparative advantages for maize, oat and wheat cropping under climate change in Europe. Food Addit. Contam.: Part A 29, 1514-1526. http://dx.doi.org/10.1080/19440049.2012.700953.

Ergon, Å., Kirwan, L., Fystro, G., Bleken, M.Å., Collins, R.P., Rognli, O.Å., 2017. Species interactions in a grassland mixture under low nitrogen fertilization and two cutting frequencies. II. Nutritional quality. Grass Forage Sci. 72, 333-342. http://dx.doi.org/ $10.1111 / \mathrm{gfs} .12257$.

Ergon, A., 2017. Optimal regulation of the balance between productivity and overwintering of perennial grasses in a warmer climate. Agronomy 7, 19. http://dx.doi. org/10.3390/agronomy7010019.

Fariaszewska, A., Aper, J., Van Huylenbroeck, J., Baert, J., De Riek, J., Staniak, M., Pecio, Ł., 2016. Mild drought stress-induced changes in yield, physiological processes and chemical composition in Festuca, Lolium and Festuolium. J. Agron. Crop Sci. 203, 103-116. http://dx.doi.org/10.1111/jac.12168.

Franca, A., Seddaiu, G., Caredda, S., 2005. Morphological adaptation of Lolium rigidum Gaudin to different conditions of the Mediterranean semi-arid environment. Agric. Medit. 135, 202-208.

Gepstein, S., 2004. Leaf senescence - not just a 'wear and tear' phenomenon. Genome Biol. 5.

Giannakopoulos, C., Le Sager, P., Bindi, M., Moriondo, M., Kostopoulou, E., Goodess, C.M., 2009. Climatic changes and associated impacts in the Mediterranean resulting from a 2 degrees C global warming. Global Planet. Change 68, 209-224.

Gillespie, L.M., Volaire, F.A., 2017. Are winter and summer dormancy symmetrical seasonal adaptive strategies? The case of temperate herbaceous perennials. Ann. Bot. 119, 311-323. http://dx.doi.org/10.1093/aob/mcw264.

Giorgi, F., Lionello, P., 2008. Climate change projections for the Mediterranean region. Global Planet. Change 63, 90-104.

Goslee, S.C., Veith, T.L., Skinner, R.H., Comas, L.H., 2013. Optimizing ecosystem function by manipulating pasture community composition. Basic Appl. Ecol. 14, 630-641. http://dx.doi.org/10.1016/j.baae.2013.09.009.

Graux, A.-I., Bellocchi, G., Lardy, R., Soussana, J.F., 2013. Ensemble modelling of climate change risks and opportunities for managed grasslands in France. Agric. Forest Meteorol. 170, 114-131.

Groot, J.C.J., Lantinga, E.A., Neuteboom, J.H., Deinum, B., 2003. Analysis of the temperature effect on the components of plant digestibility in two populations of perennial ryegrass. J. Sci. Food Agric. 83, 320-329. http://dx.doi.org/10.1002/jsfa. 1315.

Höglind, M., Thorsen, S.M., Semenov, M.A., 2013. Assessing uncertainties in impact of climate change on grass production in Northern Europe using ensembles of global climate models. Agric. Forest Meteorol. 170, 103-113. http://dx.doi.org/10.1016/j agrformet.2012.02.010.

Hanssen-Bauer, I., et al., 2015. Klima i Norge 2100. NCCS-Report 2/2015. Norsk Klimasenter.

Hatfield, J.L., Prueger, J.H., 2011. Agroecology: implications for plant response to climate change. In: Yadav, S.S., Redden, R.J., Hatfield, J.L., Lotze-Campen, H., Hall, A.E.
(Eds.), Crop Adaptation to Climate Change. Wiley-Blackwell, Chichester, UK (pp. 27-43).

Helgadóttir, Á., Frankow-Lindberg, B.E., Seppänen, M.M., Søegaard, K., Østrem, L., 2014. European grasslands overview: nordic region. Grassland Sci. Eur. 19, 15-28.

Hincha, D.K., Hellwege, E.M., Heyer, A.G., Crowe, J.H., 2000. Plant fructans stabilize phosphatidylcholine liposomes during freeze-drying. Eur. J. Biochem. 267, 535-540.

Hincha, D.K., Zuther, E., Hellwege, E.M., Heyer, A.G., 2002. Specific effects of fructo- and gluco-oligosaccharides in the preservation of liposomes during drying. Glycobiology 12, 103-110.

Hoerling, M., Eischeid, J., Perlwitz, J., Quan, X.W., Zhang, T., Pegion, P., 2012. On the increased frequency of Mediterranean drought. J. Clim. 25, 2146-2161. http://dx. doi.org/10.1175/jcli-d-11-00296.1.

Humphreys, M., Macleod, C., Whalley, W., Turner, L., Farrell, M., Ghesquière, M., Haygarth, P., 2012. Designing grass cultivars for droughts and floods. In: Barth, S., Milbourne, D. (Eds.), Breeding Strategies for Sustainable Forage and Turf Grass Improvement. Springer Dordrech (pp. 171-179.).

Huyghe, C., De Vliegher, A., van Gils, B., Peeters, A., 2014. Grasslands and Herbivore Production in Europe and Effects on Common Policies. Editions Quæ, France (ISBN 978-2-7592-2156-1).

Irigoyen, J.J., Goicoechea, N., Antolín, M.C., Pascual, I., Sánchez-Díaz, M., Aguirreolea, J., Morales, F., 2014. Growth, photosynthetic acclimation and yield quality in legumes under climate change simulations: an updated survey. Plant Sci. 226, 22-29.

Jørgensen, M., Østrem, L., Höglind, M., 2010. De-hardening in contrasting cultivars of timothy and perennial ryegrass during winter and spring. Grass Forage Sci. 65, 38-48.

Jørgensen, M., Mølmann, J., Taff, G., 2016. Impact of waterlogging under different temperatures on hardening and freezing tolerance of timothy (Phleum pratense). Grassland Sci. Eur. 21, 814-816.

Jepsen, J.U., Kapari, L., Hagen, S.B., Schott, T., Vindstad, O.P.L., Nilssen, A.C., Ims, R.A., 2011. Rapid northwards expansion of a forest insect pest attributed to spring phenology matching with sub-Arctic birch. Global Change Biol. 17, 2071-2083. http:// dx.doi.org/10.1111/j.1365-2486.2010.02370.x.

Jing, Q., Bélanger, G., Qian, B., Baron, V., 2013. Timothy yield and nutritive value under climate change in Canada. Agron. J. 105, 1683-1694.

Johansson, C., Pohjola, V.A., Jonasson, C., Callaghan, T.V., 2011. Multi-decadal changes in snow characteristics in sub-Arctic Sweden. Ambio 40, 566-574. http://dx.doi.org/ 10.1007/s13280-011-0164-2.

Juroszek, P., von Tiedemann, A., 2013. Plant pathogens, insect pests and weeds in a changing global climate: a review of approaches, challenges, research gaps, key studies and concepts. J. Agric. Sci. 151, 163-188. http://dx.doi.org/10.1017/ S0021859612000500.

Källomäki, S., Maajärvi, M., Strandman, H., Kilpeläinen, A., Peltola, H., 2010. Model computations on the climate change effects on snow cover, soil moisture and soil frost in the boreal conditions over Finland. Silva Fennica 44, 213-233.

Köchy, M., Mathaj, M., Jeltsch, F., Malkinson, D., 2008. Resilience of stocking capacity to changing climate in arid to Mediterranean landscapes. Reg. Environ. Change 8, 73-87.

Kallida, R., Zhouri, L., Volaire, F., Guerin, A., Julier, B., Shaimi, N., Fakiri, M., Barre, P., 2016. Combining drought survival via summer dormancy and annual biomass productivity in Dactylis glomerata L. Front. Plant Sci. 7, 82. http://dx.doi.org/10.3389/ fpls.2016.00082.

Karcher, D.E., Richardson, M.D., Hignight, K., Rush, D., 2008. Drought tolerance of tall fescue populations selected for high root/shoot ratios and summer survival. Crop Sci. 48, 771-777.

Kovats, R.S., Valentini, R.S., Bouwer, L.M., Georgopoulou, E., Jacob, D., Martin, E., Rounsevell, M., Soussana, J.-F., et al., 2014. Europe. In: Barros, V.R. (Ed.), Climate Change 2014: Impacts, Adaptation, and Vulnerability. Part B: Regional Aspects. Contribution of Working Group II to the Fifth Assessment Report of the Intergovernmental Panel on Climate. Change Cambridge University Press, Cambridge, United Kingdom and New York, NY, USA 1267-1326.

Lüscher, A., Daepp, M., Blum, H., Hartwig, U.A., Nösberger, J., 2004. Fertile temperate grassland under elevated atmospheric $\mathrm{CO} 2$ - role of feed-back mechanisms and availability of growth resources. Eur. J. Agron. 21, 379-398.

Lüscher, A., Mueller-Harvey, I., Soussana, J.F., Rees, R.M., Peyraud, J.L., 2014. Potential of legume-based grassland-livestock systems in Europe: a review. Grass Forage Sci. 69, 206-228.

Laude, H.M., 1953. The nature of summer dormancy in perennial grasses. Botanical Gazette 114, 282-292.

Leakey, A.D., Ainsworth, E.A., Bernacchi, C.J., Rogers, A., Long, S.P., Ort, D.R., 2009. Elevated $\mathrm{CO} 2$ effects on plant carbon, nitrogen, and water relations: six important lessons from FACE. J. Exp. Bot. 60, 2859-2876.

Lehtonen, I., Ruosteenoja, K., Jylhä, K., 2014. Projected changes in European extreme precipitation indices on the basis of global and regional climate model ensembles. Int. J. Climatol. 34, 1208-1222.

Lelièvre, F., Volaire, F., 2009. Current and potential development of perennial grasses in rainfed Mediterranean farming systems. Crop Sci. 49, 2371-2378.

Long, R.L., Gorecki, M.J., Renton, M., Scott, J.K., Colville, L., Goggin, D.E., Commander, L.E., Westcott, D.A., Cherry, H., Finch-Savage, W.E., 2015. The ecophysiology of seed persistence: a mechanistic view of the journey to germination or demise. Biol. Rev. 90, 31-59.

Mäkinen, H., Kaseva, J., Virkajärvi, P., Kahiluoto, H., 2015. Managing resilience of forage crops to climate change through response diversity. Nat. Field Crops Res. 183, 23-30.

Mäkinen, H., Kaseva, J., Virkajärvi, P., Kahiluoto, H., 2016. Gaps in the capacity of modern forage crops to adapt to the changing climate in northern Europe. Mitig. Adapt. Strat. Global Change. http://dx.doi.org/10.1007/s11027-016-9729-5.

Malinowski, D.O., Zuo, H., Kramp, B.A., Muir, J.P., Pinchak, W.E., 2005. Obligatory 
summer-dormant cool-season perennial grasses for semiarid environments of the southern Great Plains. Agron. J. 97, 147-154.

Malinowski, D.P., Kigel, J., Pinchak, W.E., 2009. Water deficit, heat tolerance, and per sistence of summer-dormant grasses in the U.S. Southern Plains. Crop Sci. 49, 2363-2370.

Maltoni, S., Molle, G., Porqueddu, C., Connolly, J., Brophy, C., Decandia, M., 2007. The potential feeding value of grass-legume mixtures in dry Mediterranean conditions. In: Helgadottir, A., Potsch, E. (Eds.), Final Meeting of COST Action 852. RaumbergGumpenstein (Austria) 30 August ?3 September 2006. Irdning, Austria. pp. 149-152.

McWilliam, J.R., Kramer, P.J., 1968. The nature of the perennial response in Mediterranean grasses. 1. Water relations and summer survival in Phalaris. Aust. J. Agric. Res. 19, 381-395.

Metzger, M.K., Bunce, R.G.H., Jongman, R.H.G., Mücher, C.A., Watkins, J.W., 2005. A climatic stratification of the environment in Europe. Global Ecol. Biogeogr. 14, 549-563.

Mikkonen, S., Laine, M., Mäkelä, H.M., Gregow, H., Tuomenvirta, H., Lahtinen, M., Laaksonen, A., 2015. Trends in the average temperature in Finland, 1847-2013. Stochastic Environ. Res. Risk Assess. 29, 1521-1529.

Milbau, A., Scheerlinck, L., Reheul, D., De Cauwer, B., Nijs, I., 2005. Ecophysiological and morphological parameters related to survival in grass species exposed to an extreme climatic event. Physiol. Plant. 125, 500-512.

Moreno, G., Pulido, F., 2009. The functioning, management and persistence of Dehesas. In: Rigueiro-Rodríguez, A., McAdam, J., Mosquera-Losada, M.R. (Eds.), Agroforestry in Europe. Springer (pp. 127-160).

Morgan, J.A., Pataki, D.E., Körner, C., Clark, H., Del Grosso, S.J., Grünzweig, J.M., Knapp, A.K., Mosier, A.R., Newton, P.C.D., Niklaus, P.A., Nippert, J.B., Nowak, R.S., Parton, W.J., Polley, H.W., Shaw, M.R., 2004. Water relations in grassland and desert ecosystems exposed to elevated atmospheric CO2. Oecologia 140, 11-25. http://dx.doi. org/10.1007/s00442-004-1550-2.

Morgan, J.M., 1988. Physiological Traits for Drought Resistance. Drought resistance in cereals CAB International, Wallingford, UK.

Munne Bosch, S., Alegre, L., 2004. Die and let live: leaf senescence contributes to plant survival under drought stress. Funct. Plant Biol. 31, 203-216.

Nesheim, L., Boller, B., 1991. Nitrogen fixation by white clover when competing with grasses at moderately low temperatures. Plant Soil 133, 47-56.

Nevens, F., Reheul, D.1, 2003. Effects of cutting or grazing grass swards on herbage yield, nitrogen uptake and residual soil nitrate at different levels of $\mathrm{N}$ fertilization. Grass Forage Sci. 58, 431-449.

Nichols, P.G.H., Revell, C.K., Humphries, A.W., Howie, J.H., Hall, E.J., Sandral, G.A. Ghamkhar, K., Harris, C.A., 2012. Temperate pasture legumes in Australia - their history, current use, and future prospects. Crop Pasture Sci. 63, 691-725. http://dx. doi.org/10.1071/CP12194.

Norton, M.R., Volaire, F., Lelièvre, F., Fukai, S., 2009. Identification and measurement of summer dormancy in temperate perennial grasses. Crop Sci. 49, 2347-2352.

Norton, M.R., Malinowski, D.P., Volaire, F., 2016. Plant drought survival under climate change and strategies to improve perennial grasses: a review. Agron. Sustainable Dev. 36, 21. http://dx.doi.org/10.1007/s13593-016-0362-1.

Olesen, J.E., Trnka, M., Kersebaum, K.C., Skjelvåg, A.O., Seguin, B., Peltonen-Sainio, P., Rossi, F., Kozyra, J., Micale, F., 2011. Impacts and adaptation of European crop production systems to climate change. Eur. J. Agron. 34, 96-112.

Ooi, M.K.J., 2012. Seed bank persistence and climate change. Rev. Seed Sci. Res. 22 53-60.

Oram, R., Lodge, G., 2003. Trends in temperate Australian grass breeding and selection. Aust. J. Agric. Res. 54, 211-241.

Østrem, L., Volden, B., Larsen, A., 2013. Morphology, dry matter yield and phenological characters at different maturity stages of $\times$ Festulolium compared with other grass species. Acta Agric. Scand. Sect. B - Soil Plant Sci. 63, 531-542.

Østrem, L., Rapacz, M., Larsen, A., Dalmannsdottir, S., Jørgensen, M., 2014. Influences of growth cessation and photoacclimation on winter survival of non-native LoliumFestuca grasses in high-latitude regions. Environ. Exp. Bot. 111, 21-31.

Pahl, L., Scanlan, J., Whish, G., Cowley, R., MacLeod, N., 2016. Comparing fixed and flexible stocking as adaptations to inter-annual rainfall variability in the extensive beef industry of northern Australia. Rangeland J. 38, 85-102.

Papanastasis, V.P., Yiakoulaki, M.D., Decandia, M., Dini-Papanastasi, O., 2008. Integrating woody species into livestock feeding in the Mediterranean areas of Europe. Anim. Feed Sci. Technol. 140, 1-17.

Pecetti, L., Annicchiarico, P., Porqueddu, C., Khedim, A., Abdelguerfi, A., 2009. Fitting germplasm types of tall fescue and orchardgrass to different cropping environments of the Mediterranean region. Crop Sci. 49, 2393-2399.

Pecetti, L., Annicchiarico, P., Abdelguerfi, A., Kallida, R., Mefti, M., Porqueddu, C. Simoes, N.M., Volaire, F., Lelievre, F.1, 2011. Response of Mediterranean tall fescue cultivars to contrasting agricultural environments and implications for selection. J. Agron. Crop Sci. 197, 12-20. http://dx.doi.org/10.1111/j.1439-037X.2010.00443.x.

Peeters, A., Beaufoy, G., Canals, R.M., Vliegher, A., Huyghe, C., Isselstein, J., Jones, G., Kessler, W., Kirilov, A., Mosquera-Losada, M.R., Nilsdotter-Linde, N., Parent, G., Peyraud, J.L., Pickert, J., Plantureux, S., Porqueddu, C., Rataj, D., Stypinski, P., Tonn, B., van den Pol-van Dasselaar, A., Vintu, V., Wilkins, R.J., 2014. Grassland term definitions and classifications adapted to the diversity of EU grassland-based systems. Grassland Sci. Eur. 19, 743-750.

Peltonen-Sainio, P., Rajala, A., Känkänen, H., Hakala, K., 2009. Improving farming systems in Northern European conditions. In: Sadras, Calderini (Eds.), Crop Physiology. Applications for Genetic Improvement and Agronomy. Elsevier ISBN 978-0-12374431-9, p. 71-97.

Picon-Cochard, C., Teyssonneyre, F., Besle, J.M., Soussana, J.F., 2004. Effects of elevated $\mathrm{CO} 2$ and cutting frequency on the productivity and herbage quality of a semi-natural grassland. Eur. J. Agron. 20, 363-377.
Piva, A., Bertrand, A., Bélanger, G., Castonguay, Y., Seguin, P., 2013. Growth and physiological response of timothy to elevated carbon dioxide and temperature under contrasted nitrogen fertilization. Crop Sci. 53, 1-12.

Porqueddu, C., Gonzalez, F., 2006. Role and potential of annual pasture legumes in Mediterranean farming systems. Grassland Sci. Eur. 11, 221-231.

Porqueddu, C., Maltoni, S., 2007. Biomass production and unsown species control in rainfed grass legume mixtures in a Mediterranean environment. In: Helgadottir, A. Potsch, E. (Eds.), Proceedings of the COST 852 Final Meeting. 30 August-3 September 2006, Raumberg-Gimpenstein, Austria Irdning Austria. pp. 41-44.

Porqueddu, C., Ates, S., Louhaichi, M., Kyriazopoulos, A.P., Moreno, G., del Pozo, A., Ovalle, C., Ewing, M.A., Nichols, P.G.H., 2016. Grasslands in 'Old world' and 'New world' Mediterranean-climate zones: past trends, current status and future research priorities. Grass Forage Sci. 1-35. http://dx.doi.org/10.1111/gfs/12212.

Porqueddu, C., 2001. Screening germplasm and varieties for forage quality: constraints and potentials in annual medics. In: Delgado, I., Lloveras, J. (Eds.), Quality in Lucerne and Medics for Animal Production. CIHEAM, Zaragoza (pp. 89-98).

Porter, J.R., Xie, L., Challinor, A.J., Cochrane, K., Howden, S.M., Iqbal, M.M., Lobell, D.B., Travasso, M.I., et al., 2014. Food security and food production systems. In: Field, C.B. (Ed.), Climate Change 2014: Impacts, Adaptation, and Vulnerability. Part A: Global and Sectoral Aspects. Contribution of Working Group II to the Fifth Assessment Report of the Intergovernmental Panel on Climate Change. Cambridge University Press, Cambridge, United Kingdom and New York, NY, USA. pp. 485-533.

Preston, J.C., Sandve, S.R., 2013. Adaptation to seasonality and the winter freeze. Front. Plant Sci. 4, 167. http://dx.doi.org/10.3389/fpls.2013.00167.

Räisänen, J., Eklund, J., 2011. 21 st Century changes in snow climate in Northern Europe: a high-resolution view from ENSEMBLES regional climate models. Clim. Dyn. 38, 2575-2591. http://dx.doi.org/10.1007/s00382-011-1076-3.

Rapacz, M., Ergon, Å, Höglind, M., Jørgensen, M., Jurczyk, B., Østrem, L., Rognli, O.A., Tronsmo, A.M., 2014. Overwintering of herbaceous plants in a changing climate: still more questions than answers. Plant Sci. 225, 34-44.

Rivedal, S., Riley, H., Lunnan, T., Stürite, I., 2016. Effects of tractor traffic on soil compaction and grassland yield. Grassland Sci. Eur. 21, 774-776.

Rogers, A.L., Nicholas, D.A., Maller, R.A., Arnold, G.W., 1976. Yield and persistence of selected perennial grasses in south-western Australia. Aust. J. Exp. Agric. Anim. Husb. 16, 522-531.

Rogers, A., Fischer, B.U., Bryant, J., Frehner, M., Blum, H., Raines, C.A., Long, S.P., 1998. Acclimation of photosynthesis to elevated $\mathrm{CO} 2$ under low-nitrogen nutrition is affected by the capacity for assimilate utilization. Perennial ryegrass under free-air $\mathrm{CO} 2$ enrichment. Plant Physiol. 118, 683-689.

Roy, J., Picon-Cochard, C., Augusti, A., Benot, M.L., Thiery, L., Darsonville, O., Landais, D., Piel, C., Defossez, M., Devidal, S., Escape, C., Ravel, O., Fromin, N., Volaire, F., Milcu, A., Bahn, M., Soussana, J.-F., 2016. Elevated CO2 maintains grassland net carbon uptake under a future heat and drought extreme. PNAS 113, 6224-6229.

Ruosteenoja, K., Räisänen, P., 2013. Seasonal changes in solar radiation and relative humidity in Europe in response to global warming. J. Climatol. 26, 2467-2481. http://dx.doi.org/10.1175/JCLI-D-12-00007.1.

Ruosteenoja, K., Tuomenvirta, H., Jylhä, K., 2007. GCM-based regional temperature and precipitation change estimates for Europe under four SRES scenarios applying a super-ensemble pattern.scaling method. Climatic Change 81, 193-208. http://dx.doi. org/10.1007/s10584-006-922-3.

Ruosteenoja, K., Räisänen, J., Pirinen, P.1, 2011. Projected changes in thermal seasons and the growing season in Finland. Int. J. Climatol. 31, 1473-1487.

Ruosteenoja, K., Jylhä, K., Kämäräinen, M., 2016. Climate projections for Finland under the RCP forcing scenarios. Geophysica 51, 17-50.

Saarijärvi, K., Virkajärvi, P., Heinonen-Tanski, H., Taipalinen, I., 2004. N and P leaching and microbial contamination from intensively managed pasture and cut sward on sandy soil in Finland. Agric. Ecosyst. Environ. 104 (3), 621-630.

Saarijärvi, K., Virkajärvi, P., Heinonen-Tanski, H., 2007. Nitrogen leaching and herbage production on intensively managed grass and grass-clover pastures on sandy soil in Finland. Eur. J. Soil Sci. 58, 1382-1392.

Salis, L., Sitzia, M., Vargiu, M., Mullè, P., Re, G.A., Sulas, L., 2012. Adaptation of Australian self-reseeding forage legumes to three environments of Sardinia. Opt. Mediterraneennes 102, 265-269.

Sanderson, M.A., 2010. Stability of production and plant species diversity in managed grasslands: a retrospective study. Basic Appl. Ecol. 11, 216-224.

Serraj, R., Sinclair, T.R., 2002. Osmolyte accumulation: can it really help increase crop yield under drought conditions? Plant Cell Environ. 25, 333-341. http://dx.doi.org/ 10.1046/j.1365-3040.2002.00754.x.

Sleugh, B., Moore, K.K., George, J.R., Brummer, E.C., 2000. Binary legume-grass mixtures improve forage yield, quality, and seasonal distribution. Agron. J. 92, 24-29.

Soussana, J.-F., Hartwig, U.A., 1996. The effects of elevated CO2 on symbiotic N2 fixation: a link between the carbon and nitrogen cycles in grassland ecosystems. Plant Soil 187, 321-332.

Soussana, J.-F., Lüscher, A., 2007. Temperate grasslands and global atmospheric change: a review. Grass Forage Sci. 62, 127-134.

Soussana, J.-F., Graux, A.I., Tubiello, F.N., 2010. Improving the use of modelling for projections of climate change impacts on crops and pastures. J. Exp. Bot. 61, 2217-2228.

Sternberg, M., Golodets, C., Gutman, M., Perevolotsky, A., Ungar, E.D., Kigel, J., Henkin, Z., 2015. Testing the limits of resistance: a 19-year study of Mediterranean grassland response to grazing regimes. Global Change Biol. 21, 1939-1950.

Stuart, M.E., Gooddy, D.C., Bloomfield, J.P., Williams, A.T., 2011. A review of the impact of climate change on future nitrate concentrations in groundwater of the UK. Sci. Total Environ. 409, 2859-2873.

Sulas, L., 2005. The future role of forage legumes in Mediterranean-climate areas. In: Reynolds, S., Frame, J. (Eds.), Grasslands: Developments Opportunities Perspectives. 
FAO and Plymouth UK: Science Publishers, Inc, Rome, pp. 29-54.

Svobodová, E., Trnka, M., Dubrovský, M., Semerádová, D., Eitzinger, J., Štěpánek, P., Žalud, Z., 2014. Determination of areas with the most significant shift in persistence of pests in Europe under climate change. Pest. Manag. Sci. 70, 708-715. http://dx. doi.org/10.1002/ps.3622.

Taylor, G.B., 2005. Hardseededness in Mediterranean annual legumes in Australia: a review. Aust. J. Agric. Res. 56, 645-661.

Thivierge, M.-N., Jégo, G., Bélanger, G., Bertrand, A., Tremblay, G.F., Rotz, C.A., 2016 Predicted yield and nutritive value of an alfalfa-timothy mixture under climate change and elevated atmospheric carbon dioxide. Agron. J. 108. http://dx.doi.org/ 10.2134/agronj2015.0484.

Thorvaldsson, G., Tremblay, G.F., Kunelius, H.T., 2007. The effects of growth temperature on digestibility and fibre concentration of seven temperate grass species. Acta Agric. Scand. Sect. B - Soil Plant Sci. 57, 322-328.

Uleberg, E., Hanssen-Bauer, I., van Oort, B., Dalmannsdottir, S., 2014. Impact of climate change on agriculture in Northern Norway and potential strategies for adaptation. Clim. Change 122, 27-39. http://dx.doi.org/10.1007/s10584-013-0983-1.

Van Peer, L., Nijs, I., Reheul, D., De Cauwer, B., 2004. Species richness and susceptibility to heat and drought extremes in synthesized grassland ecosystems: compositional vs physiological effects. Funct. Ecol. 18, 769-778. http://dx.doi.org/10.1111/j.02698463.2004.00901.x.

Vankoughnett, M.R., Way, D.A., Henry, H.A.L., 2016. Late winter light exposure increases summer growth in the grass Poa pratensis: implications for snow removal experiments and winter melt events. Environ. Exp. Bot. 131, 32-38. http://dx.doi.org/10. 1016/j.envexpbot.2016.06.014.

Vikhamar-Schuler, D., Isaksen, K., Haugen, J.E., Tømmervik, H., Luks, B., VikhamarSchuler, T., Bjerke, J.W., 2016. Changes in winter warming events in the nordic arctic region. J. Clim. 29, 6223-6244. http://dx.doi.org/10.1175/JCLI-D-15-0763.1.

Virkajärvi, P., Rinne, M., Mononen, J., Niskanen, O., Järvenranta, K., Sairanen, A., 2015. Dairy production systems in Finland. Grassland Sci. Eur. 20, 51-66.

Volaire, F., Gandoin, J.M., 1996. The effect of age of the sward on the relationship between water-soluble carbohydrate accumulation and drought survival in two contrasted populations of cocksfoot (Dactylis glomerata L.). Grass Forage Sci. 51, 190-198.
Volaire, F., Lelievre, F., 2001. Drought survival in Dactylis glomerata and Festuca arundinacea under similar rooting conditions in tubes. Plant Soil 229, 225-234.

Volaire, F., Norton, M., 2006. Summer dormancy in perennial temperate grasses. Ann. Bot. 98, 927-933.

Volaire, F., Norton, M.R., Lelievre, F., 2009. Summer drought survival strategies and sustainability of perennial temperate forage grasses in Mediterranean areas. Crop Sci. 49, 2386-2392. http://dx.doi.org/10.2135/cropsci2009.06.0317.

Volaire, F., Barkaoui, K., Norton, M., 2014. Designing resilient and sustainable grasslands for a drier future: adaptive strategies, functional traits and biotic interactions. Eur. J. Agron. 52, 81-89.

Volaire, F., Kallida, R., Norton, M., Malinowski, D., Barre, P., 2016. Fodder grass selection in the Mediterranean, the role of summer dormancy. In: Allenvi - IRD (Ed.), The Mediterranean Region Under Climate Change. A Scientific Update, Marseille. pp. 495-501.

Volaire, F., 1994. Effects of summer drought and spring defoliation on carbohydrate reserves, persistence and recovery of two populations of cocksfoot (Dactylis glomerata) in a Mediterranean environment. J. Agric. Sci. 122, 207-215.

Wasson, A.P., Richards, R.A., Chatrath, R., Misra, S.C., Prasad, S.V.S., Rebetzke, G.J., Kirkegaard, J.A., Christopher, J., Watt, M., 2012. Traits and selection strategies to improve root systems and water uptake in water-limited wheat crops. J. Exp. Bot. 63, 3485-3498. http://dx.doi.org/10.1093/jxb/ers111.

White, T.A., Snow, V.O., 2012. A modelling analysis to identify plant traits for enhanced water-use efficiency of pasture. Crop Pasture Sci. 63, 63-76. http://dx.doi.org/10. $1071 / \mathrm{cp} 11250$.

Xu, Z., Shimizu, H., Yagasaki, Y., Ito, S., Zheng, Y., Zhou, G., 2013. Interactive effects of elevated CO2, drought, and warming on plants. J. Plant Growth Regul. 32, 692-707. http://dx.doi.org/10.1007/s00344-013-9337-5.

Zeeman, M.J., Mauder, M., Steinbrecher, R., Heidbach, K., Eckart, E., Schmids, H.P. 2017. Reduced snow cover affects productivity of upland temperategrassland. Agric. Forest Meteorol. 232, 514-526. http://dx.doi.org/10.1016/j.agrformet.2016.09.002.

Zwicke, M., Picon-Cochard, C., Morvan-Bertrand, A., Prud'homme, M.-P., Volaire, F., 2015. What functional strategies drive drought survival and recovery of perennial species from upland grassland? Ann. Bot. 116, 1001-1015. http://dx.doi.org/10. 1093/aob/mcv037. 